\title{
Gene Expression Analyses in Early Breast Carcinoma - Quo Vadis?
}

\section{Genexpressionsanalysen beim frühen Mammakarzinom - quo vadis?}

Authors

Katrin Almstedt ${ }^{1}$, Carsten Denkert ${ }^{2}$, Marcus Schmidt ${ }^{1}$

\section{(ㄷ) (1) $(9)$}

Affiliation

1 Section of Conservative and Molecular Gynecological Oncology, Department of Obstetrics and Gynecology, Mainz, University Medical Center, Mainz, Germany

2 Institute of Pathology, Charité, Campus Charité Mitte, Charité - Universitätsmedizin Berlin, Berlin, Germany

Key words

gene expression, breast carcinoma, intrinsic subtypes, prognosis, evidence

Schlüsselwörter

Genexpression, Mammakarzinom, intrinsische Subtypen, Prognose, Evidenz

Bibliography

DOI https://doi.org/10.1055/s-0043-122833

Senologie 2017; 14: 209-213

(c) Georg Thieme Verlag KG, Stuttgart · New York

ISSN 1611-6453

Correspondence

Univ.-Prof. Dr. Marcus Schmidt

Abteilung für Konservative und Molekulare Gynäkologische Onkologie

Klinik und Poliklinik für Geburtshilfe und Frauengesundheit Universitätsmedizin Mainz, Langenbeckstr. 1, 55131 Mainz

Tel.: ++49/6131/173291

Fax: ++49/6131/175673

marcus.schmidt@unimedizin-mainz.de

\section{ZUSAMMENFASSUNG}

Zur Festlegung der adjuvanten Therapie beim Mammakarzinom ist eine möglichst genaue Einschätzung des Risikos für einen Rückfall von entscheidender Bedeutung. In diesem Zusammenhang sind die Genexpression und damit auch Genexpressionssignaturen als Prognosefaktoren in den Mittelpunkt des Interesses gerückt. Für den praktischen Einsatz ist es wichtig, dass Genexpressionssignaturen an formalinfixiertem, paraffineingebettetem Tumorgewebe durchgeführt werden können. Um eine ungenaue Risikoklassifikation und damit eine mögliche Unter- oder Übertherapie der Patientinnen zu vermeiden, müssen sorgfältige analytische und klinische Validierungen und ein hoher Level of Evidence (LoE) gefordert werden. Von den kommerziell erhältlichen Genexpressionssignaturen werden derzeit MammaPrint ${ }^{\circledR}$ und Oncotype $D X^{\circledR}$ mit prospektiven Studienergebnissen als LoE IA sowie Endopredict ${ }^{\circledR}$ und Prosigna ${ }^{\circledR}$ als LoE IB von der Arbeitsgemeinschaft Gynäkologische Onkologie (AGO) eingestuft. Ebenso votierten die Panelmitglieder der diesjährigen St. Gallen Konsensuskonferenz mehrheitlich für den möglichen Einsatz von Oncotype DX ${ }^{\circledR}$, MammaPrint ${ }^{\circledR}$, Prosigna ${ }^{\circledR}$, EndoPredict ${ }^{\circledR}$ und Breast Cancer Index ${ }^{\circledR}$. Diese Multigentests können bei ausgewählten hormonrezeptorpositiven und HER2negativen Patientinnen eingesetzt werden, wenn alle anderen Kriterien keine Therapieentscheidung zulassen.

\section{ABSTRACT}

In order to establish whether adjuvant therapy should be administered in patients with breast carcinoma, it is decisive to have as precise as possible an assessment of the risk of recurrence. In this context, gene expression - and thus gene expression signatures as well - have become a focus of attention as prognostic factors. For practical application, it is important to be able to analyze gene expression signatures in formalin-fixed, paraffin-embedded tumor tissue. Careful analytic and clinical validations and a high level of evidence (LoE) are required in order to avoid imprecise risk classification and thus potential overtreatment or undertreatment of the patients. Among the commercially available gene expression signatures, the Working Group on Gynecological Oncology (Arbeitsgemeinschaft Gynäkologische Onkologie, AGO) currently grades MammaPrint ${ }^{\circledR}$ and Oncotype DX ${ }^{\circledR}$ as having LoE $I A$, with prospective study results; and Endopredict ${ }^{\circledR}$ and Prosigna ${ }^{\circledR}$ as having LoE IB. The panel members at this year's St. Gallen consensus conference also voted by a majority in favor of the possible usage of Oncotype DX ${ }^{\circledR}$, MammaPrint ${ }^{\circledR}$, Prosigna $^{\circledR}$, EndoPredict ${ }^{\circledR}$, and Breast Cancer Index ${ }^{\circledR}$. These multigene tests can be used in selected patients with hormone receptor-positive and HER2-negative findings if none of the other criteria allow a treatment decision to be made. 


\section{Introduction}

Patients with breast carcinoma may benefit from adjuvant chemotherapy [1]. However, the treatment can lead to adverse side effects, ranging from acute toxicities (e. g., alopecia, nausea, vomiting) to conditions potentially reducing the long-term quality of life (e. g., amenorrhea, fatigue, sensory polyneuropathy, and "chemo brain"), or even to potentially life-threatening conditions (e. g., cardiac insufficiency and secondary leukemia) [2]. In view of this dilemma, it is extremely important to carry out as precise as possible an assessment of the risk of recurrence. The basic pillars of risk assessment are the classic clinical and pathological prognostic factors (tumor size, nodal status, grade of histological differentiation, estrogen receptor [ER], progesterone receptor [PR], HER2 status, and Ki-67 as a proliferation marker). In this context, gene expression analyses are also playing an increasingly important role. Assessment of the probable risk of recurrence is essential, since patients with a low level of absolute risk only have a slight absolute benefit from adjuvant chemotherapy [1]. For this reason, it is decisive for gene expression analyses in breast carcinoma to be assessed using clear evidence criteria [3]. The long march of gene expression analyses of thousands of genes involved in breast carcinoma was pioneered by Perou and co-workers in 2000. The molecular heterogeneity of breast carcinomas was demonstrated using DNA microarrays, and a new nomenclature for breast carcinoma was defined through the identification of what are known as "intrinsic subtypes" [4].

\section{Evidence classification with prognostic factors}

In principle, a priori research in prospective and randomized studies is still regarded as the gold standard. However, since such research to evaluate prognostic factors like gene expression is extremely costly and elaborate, "prospective-retrospective" approaches using archived material from prospective studies have been reported [3].

\section{Commercially available gene expression tests in breast cancer - prospective- retrospective evidence}

\section{Prosigna ${ }^{\circledR}$ (PAM50)}

Fifty genes (PAM50) from the original list of intrinsic genes were investigated using quantitative real-time polymerase chain reaction (qRT-PCR) in paraffin-embedded tissue [5]. This gene signature was reduced to 46 genes for the commercially available gene expression test Prosigna ${ }^{\circledR}$ (NanoString Technologies, Seattle, Washington, USA) and has so far been validated in a "prospective-retrospective" fashion in several studies [6]. These investigations basically confirmed that hormone receptor-positive luminal breast carcinomas can be classified into two groups with clearly differing prognoses. Luminal A carcinomas have a better prog- nosis than the faster-proliferating luminal B carcinomas. A basic problem particularly with hormone receptor-positive breast carcinomas is the development of late metastases more than 5 years after surgery. In the prospective-retrospective ABCSG 8 study, Filipits et al. showed that using PAM50 made it possible to identify a low-risk group with a risk of $2.4 \%$ after 5 years of endocrine therapy [7].

\section{MammaTyper ${ }^{\circledR}$}

The difference between luminal A and luminal B differentiated breast carcinomas, which is also reflected in the current St. Gallen classification, is mainly assessed by measuring the proliferation rate using Ki-67. Research on ways of measuring Ki-67 mRNA using qRT-PCR is currently ongoing. In an analysis of the FinHER study, for example, Wirtz et al. have shown that mRNA assessment of Ki-67, in contrast to immunohistochemical assessment, is independently associated with the distant metastasis-free survival rate (HR 0.51; $95 \% \mathrm{Cl}, 0.29$ to $0.89 ; \mathrm{P}=0.019$ ) [8]. The concordance for Ki-67 mRNA in comparison with Ki-67 immunohistochemistry was only moderate, at $75 \%$ (kappa 0.45 ). The authors concluded that mRNA assessments are more easily standardized than immunohistochemical assessments, with the known interlaboratory variability in the immunohistochemical assessment of Ki-67. In a recent international multicenter and prospective study of the gene expression test MammaTyper ${ }^{\circledR}$ (BioNTech Diagnostics $\mathrm{GmbH}$, Mainz, Germany), reproducibility was investigated for 10 types of molecular pathology [9]. The analyses showed excellent reproducibility, with kappa values between 0.9 and 1.0. MammaTyper ${ }^{\circledR}$ thus has the potential to improve decentralized assessment of formalin-fixed paraffin-embedded (FFPE) tissue samples for the established biomarkers (ER, PR, HER2, and Ki-67) and molecular subtypes.

\section{Oncotype DX ${ }^{\circledR}$}

Oncotype DX ${ }^{\circledR}$ (Genomic Health Inc., Redwood City, California, USA) is a commercially available gene expression assay that is carried out on paraffin-embedded material. It can be used in patients with hormone receptor-positive, HER2-negative early breast carcinoma (N0-1). It measures the expression of 21 genes using qRT-PCR and calculates a risk score, recurrence score (RS 0 - 100) [10]. The test made it possible to identify a low-risk group (RS $<18$ ) of patients who have a low risk of developing distant metastases with endocrine treatment alone. Additional studies have shown that low-risk patients only have a slight additional benefit from adjuvant chemotherapy $[11,12]$. The data on the occurrence of late metastases are inconsistent. In an analysis of 665 ER + node-negative patients in the TransATAC study, Oncotype DX ${ }^{\circledR}$ was not found to have any significant effect on the prediction of late metastases more than 5 years after successful surgery [13]. By contrast, a prognostic influence of Oncotype DX ${ }^{\circledR}$ on late distant metastases was demonstrated, depending on the gene expression of the estrogen receptor (ESR1) [14].

\section{EndoPredict ${ }^{\circledR}$}

The EndoPredict ${ }^{\circledR}(\mathrm{EP})$ test (Sividon Diagnostics GmbH, Cologne, Germany; distributed by Myriad Genetics Inc., Salt Lake City, 
Utah, USA) allows qRT-PCR to be carried out on paraffin-embedded material on a decentralized basis. Accurate classification of the specimens into high-risk and low-risk groups was demonstrated in interlaboratory tests [15]. Among patients in Studies 6 and 8 by the Austrian Breast Cancer Study Group (ABCSG), the EP test combined with tumor size and nodal status (EPclin) in postmenopausal ER-positive/HER2-negative patients who had only received endocrine treatment made it possible to identify a low-risk group with a 10 -year risk of distant metastases of $4 \%$. EPclin can classify $58-61 \%$ of the high-risk and intermediate-risk groups in the commonly used clinical and pathological risk classifications as a low-risk group with a 10-year metastasis risk of $5 \%$ [16], and it is also valid for the development of late metastases after 5 years of endocrine therapy [17]. The GEICAM/9906 study confirmed, as expected, that the test also had independent prognostic relevance in premenopausal patients [18].

\section{Comparison of different multigene tests}

The prospective OPTIMA Prelim study compared both risk classification and also categorization of the molecular subtypes among various commercially available gene expression tests (Oncotype DX $^{\circledR}$, Prosigna ${ }^{\circledR}$, MammaPrint $^{\circledR}$, BluePrint ${ }^{\circledR}$, MammaTyper ${ }^{\circledR}$ ) [19]. In substantial percentages of cases, both the risk classification $(60.6 \%)$ and the categorization of molecular subtypes (40.7\%) were discordant among the tests examined.

Comparisons of prognostic validity between different gene expression tests have substantial clinical importance. Direct comparison of two gene expression signatures was carried out in the TransATAC study for ER-positive/HER2-negative patients receiving endocrine treatment [8]. Results from the Oncotype DX ${ }^{\circledR}$ test for the recurrence score were already available for these patients. Using mRNA analysis, EPclin was measured using the EP test along with tumor size and nodal status. The prognostic effect was evaluated using the likelihood ratio $X^{2}\left(L R-x^{2}\right)$ and Kaplan-Meier survival time analyses for early metastases $(0-5$ years) and late metastases ( 5 - 10 years), both in node-negative and also node-positive patients. EP and EPclin were found to have greater prognostic validity than the recurrence score, particularly for node-positive tumors and late metastases. Using EPclin, $58.8 \%$ of the patients were classified as being at low risk (HR 5.99), and the recurrence score showed low risk in $61.7 \%$ (HR 2.73). These results show that it is important also to take clinical and pathological factors such as tumor size and nodal status into account alongside gene expression analyses.

\section{Commercially available multigene tests in patients with breast carcinoma - prospective evidence}

In a study including hormone receptor-positive and HER2-negative patients in the prospective and randomized PlanB study, Gluz and co-workers showed that patients with a low recurrence score $\leq 11$ who were receiving purely endocrine therapy had an excellent 3-year disease-free survival rate of $98 \%$ even without adjuvant chemotherapy [20]. The authors emphasized on the one hand that patients with a low RS had a very good prognosis with purely endocrine therapy, and on the other that the substantial discordance between traditional pathological parameters and the RS makes further standardization necessary and that wellstandardized and validated gene expression tests ought to be taken into account in the choice of treatment. In another recent analysis from the PlanB study, Nitz et al. also investigated clinical and pathological prognostic factors such as nodal status, grading, tumor size, Ki-67, PR, and four immunohistochemical markers (IHC4) alongside the recurrence score [21]. The prognostic significance of the RS was particularly marked with tumors that had moderate Ki-67 values (>10\%, <40\%). The authors concluded that Oncotype DX ${ }^{\circledR}$ can be used for treatment decision-making in patients with early breast carcinoma and $\mathrm{NO}-1$, and that Ki-67 has the potential to support the selection of patients for genome testing.

The very good survival rate in patients with hormone receptorpositive, HER2-negative tumors with a low RS $(<11)$ who are receiving purely endocrine therapy was demonstrated in the prospective and randomized TAYLORx study [22]. The 1626 patients (15.9\%) who had been classified as having low risk, with an RS $<11$, had a disease-free 5 -year survival rate of $93.8 \%$ and an overall survival rate of $98 \%$ with purely endocrine therapy. The authors therefore regarded their study as confirming that patients with a low RS can be spared adjuvant chemotherapy.

In another prospective study (MINDACT), the 70-gene signature (MammaPrint ${ }^{\circledR}$ ) was compared with clinical and pathological criteria (AdjuvantOnline ${ }^{\circledR}$ ) in patients with early breast carcinoma (node-negative, or with one to three involved lymph nodes) [23]. Patients with discordant risk classifications were randomly assigned to whether genomic $(G)$ or clinical and pathological (C) risk assessment should be used for treatment decision-making. In all, $32 \%$ had results that were discordant between $G$ and $C$ and underwent the corresponding randomization. $C$ high-risk/G low-risk patients had a metastasis-free survival rate of $94.7 \%$ if they were randomized using the genomic risk classification and thus did not receive any chemotherapy. The control group who received chemotherapy had a metastasis-free survival that was better by only $1.5 \%$. These prospective results show that the gene signature can lead overall to a substantial reduction in adjuvant chemotherapy.

\section{Evidence-based assessments of gene expression as a prognostic factor in early breast carcinoma}

The American Society of Clinical Oncology (ASCO) last year published a guideline on the use of biomarkers for adjuvant therapy decision-making in patients with early breast carcinoma [24]. The literature search for the guideline analyzed systematic review studies, meta-analyses, and randomized studies. Fifty studies from the years 2006-2014 were used to compile the guideline. One randomized prospective study and 18 prospective-retrospective studies evaluated the clinical benefit of individual 
biomarkers for decision-making on adjuvant therapy during that period. In addition to ER, PR, and HER2, adequate evidence was confirmed in node-negative patients for the clinical benefit of the multigene tests discussed above - Oncotype DX ${ }^{\circledR}$, EndoPre$\operatorname{dict}^{\circledR}$, and Prosigna ${ }^{\circledR}$ (PAM50). Following the publication of the results of the prospective MINDACT study, the ASCO this year published an updated position statement on the use of MammaPrint ${ }^{\circledR}$ gene signature assays and also confirmed the clinical benefit of the 70-gene signature profile in node-negative patients with a high level of clinical risk [25].

The European Group on Tumor Markers (EGTM) has also published up-to-date evidence-based guidelines on the use of biomarkers in patients with breast carcinoma [26]. Particularly with ER-positive, HER2-negative and node-negative breast carcinoma, gene expression signatures such as Oncotype DX ${ }^{\circledR}$, MammaPrint $^{\circledR}$, EndoPredict ${ }^{\circledR}$, Breast Cancer Index ${ }^{\circledR}(\mathrm{BCl})$ and Prosigna ${ }^{\circledR}$ (PAM50) are listed for prognostic assessment. According to this review study, Oncotype DX ${ }^{\circledR}$, MammaPrint ${ }^{\circledR}$, EndoPredict ${ }^{\circledR}$, and Prosigna ${ }^{\circledR}$ can also be used in patients with one to three involved axillary lymph nodes. In addition to the necessity of validating the tests used analytically and clinically, the importance of external quality assurance programs and regular audits and accreditations is emphasized.

However, the final report published by the Institute for Quality and Efficiency in Health Care (Institut für Qualität und Wirtschaftlichkeit im Gesundheitswesen, IQWiG) takes a contrary view [27]. Only two out of a total of eight studies used for the final report, discussed above, were taken into account [18, 23]. The final report describes the research findings as follows: "Only results from 2 of the 8 studies included could be considered in the present report. Due to the high proportion of unconsidered data, the results of the 6 remaining studies were not used for the assessment. On the basis of the 8 studies included, the data were insufficient overall to answer the research question posed." The substantial differences in the evaluation of the evidence in comparison with both the ASCO and EGTM guidelines is due to the more restrictive inclusion criteria used by IQWiG for taking studies into consideration.

Although the formal arguments against multigene tests compiled by IQWiG in this final report must be respected, from the medical point of view the question arises of whether there are currently any better tools available for analyzing gene expression using multigene tests to assess the patient's risk.

As in the findings published in the above-mentioned prognostic studies, the various gene expression signatures all have independent and in many cases also superior prognostic significance in comparison with the classic clinical and pathological prognostic factors. Although one should be aware of the limitations of multigene tests, the Working Group on Gynecological Oncology (Arbeitsgemeinschaft Gynäkologische Onkologie, AGO) has issued the following recommendation: If the conventional prognostic parameters do not allow a clear decision for or against adjuvant chemotherapy in women with ER/PR-positive, HER2negative invasive breast carcinoma, then a methodologically standardized and clinically validated multigene test can be used in decision-making. This was also the majority view of this year's St. Gallen expert panel, so that the use of multigene assays such as Oncotype DX ${ }^{\circledR}$, MammaPrint ${ }^{\circledR}$, Prosigna ${ }^{\circledR}$, EndoPredict ${ }^{\circledR}$, and Breast Cancer Index ${ }^{\circledR}(\mathrm{BCl})$ is endorsed in the expert panel's current recommendation, provided that the stated preconditions are met. The general use of gene signatures for the group of node-positive tumors is still not recommended by the panel members, although carrying out a test may also increase the prognostic validity in that group. Due to a lack of prospective data, the majority of the members voted against the use of multigene assay results as a decision-making basis for extended endocrine therapy [28].

\section{Gene expression - quo vadis?}

Risk assessment plays a central role in breast carcinoma. As molecular characterization methods are constantly improving, it will in future become possible to assess the risk better in individual patients and to administer drug therapy in a risk-adjusted way. Among the commercially available gene signatures mentioned above, Endopredict ${ }^{\circledR}$, MammaPrint ${ }^{\circledR}$, Oncotype DX ${ }^{\circledR}$, and Prosigna ${ }^{\circledR}$ are currently scored by the AGO as “+” provided that all of the other criteria do not allow a treatment decision to be made. With these preconditions, the expert panel at this year's St. Gallen international conference voted by a majority in favor of the use of Oncotype DX ${ }^{\circledR}$, MammaPrint ${ }^{\circledR}$, Prosigna ${ }^{\circledR}$, EndoPredict ${ }^{\circledR}$, and Breast Cancer Index ${ }^{\circledR}$. Assessment of gene expression as a prognostic factor - an approach that has been developing since 2000 - is thus being used increasingly for routine diagnosis in selected patients.

\section{Conflict of interest}

Professor Markus Schmidt has served as an adviser for AstraZeneca, Celgene, Eisai, Myriad, Novartis, Pfizer, Pierre-Fabre, Roche, and Sividon and has also received consultancy fees from these companies.

\section{References}

[1] Peto R, Davies C, Early Breast Cancer Trialists' Collaborative Group (EBCTCG) et al. Comparisons between different polychemotherapy regimens for early breast cancer: meta-analyses of long-term outcome among 100000 women in 123 randomised trials. Lancet 2012; 379: $432-444$

[2] Tao J], Visvanathan K, Wolff AC. Long term side effects of adjuvant chemotherapy in patients with early breast cancer. Breast 2015; 24 (Suppl. 2): S149-S153

[3] Simon RM, Paik S, Hayes DF. Use of archived specimens in evaluation of prognostic and predictive biomarkers. J Natl Cancer Inst 2009; 101: $1446-1452$

[4] Perou CM, Sørlie T, Eisen MB et al. Molecular portraits of human breast tumours. Nature 2000; 406: 747-752

[5] Parker JS, Mullins M, Cheang MCU et al. Supervised risk predictor of breast cancer based on intrinsic subtypes. J Clin Oncol 2009; 27: $1160-$ 1167

[6] Martín M, Prat A, Rodríguez-Lescure A et al. PAM50 proliferation score as a predictor of weekly paclitaxel benefit in breast cancer. Breast Cancer Res Treat 2013; 138: 457-466 
[7] Filipits M, Nielsen TO, Rudas M et al. The PAM50 risk-of-recurrence score predicts risk for late distant recurrence after endocrine therapy in postmenopausal women with endocrine-responsive early breast cancer. Clin Cancer Res 2014; 20: $1298-1305$

[8] Buus R, Sestak I, Kronenwett R et al. Comparison of EndoPredict and EPclin With Oncotype DX Recurrence Score for Prediction of Risk of Distant Recurrence After Endocrine Therapy. J Natl Cancer Inst 2016; 108: djw149

[9] Varga Z, Lebeau A, Bu H et al. An international reproducibility study validating quantitative determination of ERBB2, ESR1, PGR, and MKI67 mRNA in breast cancer using MammaTyper®. Breast Cancer Res 2017; 19: 55

[10] Paik S, Shak S, Tang G et al. A multigene assay to predict recurrence of tamoxifen-treated, node-negative breast cancer. N Engl J Med 2004; 351: $2817-2826$

[11] Paik S, Tang G, Shak S et al. Gene expression and benefit of chemotherapy in women with node-negative, estrogen receptor-positive breast cancer. J Clin Oncol 2006; 24: 3726-3734

[12] Albain KS, Barlow WE, Shak S et al. Prognostic and predictive value of the 21-gene recurrence score assay in postmenopausal women with nodepositive, oestrogen-receptor-positive breast cancer on chemotherapy: a retrospective analysis of a randomised trial. Lancet Oncol 2010; 11: 55-65

[13] Sgroi DC, Sestak I, Cuzick J et al. Prediction of late distant recurrence in patients with oestrogen-receptor-positive breast cancer: a prospective comparison of the breast-cancer index $(\mathrm{BCl})$ assay, 21-gene recurrence score, and IHC4 in the TransATAC study population. Lancet Oncol 2013; 14: $1067-1076$

[14] Wolmark N, Mamounas EP, Baehner FL et al. Prognostic Impact of the Combination of Recurrence Score and Quantitative Estrogen Receptor Expression (ESR1) on Predicting Late Distant Recurrence Risk in Estrogen Receptor-Positive Breast Cancer After 5 Years of Tamoxifen: Results From NRG Oncology/National Surgical Adjuvant Breast and Bowel Project B-28 and B-14. J Clin Oncol 2016; 34: 2350-2358

[15] Denkert C, Kronenwett R, Schlake W et al. Decentral gene expression analysis for $E R+/ H e r 2-$ breast cancer: results of a proficiency testing program for the EndoPredict assay. Virchows Arch 2012; 460: 251 - 259

[16] Dubsky P, Filipits M, Jakesz R et al. EndoPredict improves the prognostic classification derived from common clinical guidelines in ER-positive, HER2-negative early breast cancer. Ann Oncol 2013; 24: 640-647

[17] Dubsky P, Brase JC, Jakesz R et al. The EndoPredict score provides prognostic information on late distant metastases in ER+/HER2- breast cancer patients. Br J Cancer 2013; 109: 2959-2964
[18] Martin M, Brase JC, Calvo L et al. Clinical validation of the EndoPredict test in node-positive, chemotherapy-treated ER+/HER2- breast cancer patients: results from the GEICAM 9906 trial. Breast Cancer Res 2014; 16: R38

[19] Bartlett JMS, Bayani ], Marshall A et al. Comparing Breast Cancer Multiparameter Tests in the OPTIMA Prelim Trial: No Test Is More Equal Than the Others. J Natl Cancer Inst 2016; 108: djw050

[20] Gluz O, Nitz UA, Christgen M et al. West German Study Group Phase III PlanB Trial: First Prospective Outcome Data for the 21-Gene Recurrence Score Assay and Concordance of Prognostic Markers by Central and Local Pathology Assessment. J Clin Oncol 2016; 34: 2341 - 2349

[21] Nitz U, Gluz O, Christgen M et al. Reducing chemotherapy use in clinically high-risk, genomically low-risk pN0 and pN1 early breast cancer patients: five-year data from the prospective, randomised phase 3 West German Study Group (WSG) PlanB trial. Breast Cancer Res Treat 2017; 165: $573-583$

[22] Sparano JA, Gray RJ, Makower DF et al. Prospective Validation of a 21Gene Expression Assay in Breast Cancer. N Engl J Med 2015; 373: 2005 2014

[23] Cardoso F, van't Veer L], Bogaerts ] et al. 70-Gene Signature as an Aid to Treatment Decisions in Early-Stage Breast Cancer. N Engl J Med 2016; 375: $717-729$

[24] Harris LN, Ismaila N, McShane LM et al. Use of Biomarkers to Guide Decisions on Adjuvant Systemic Therapy for Women With Early-Stage Invasive Breast Cancer: American Society of Clinical Oncology Clinical Practice Guideline. J Clin Oncol 2016; 34: 1134-1150

[25] Krop I, Ismaila N, Andre F et al. Use of Biomarkers to Guide Decisions on Adjuvant Systemic Therapy for Women With Early-Stage Invasive Breast Cancer: American Society of Clinical Oncology Clinical Practice Guideline Focused Update. J Clin Oncol 2017; 35: 2838-2847

[26] Duffy M], Harbeck N, Nap M et al. Clinical use of biomarkers in breast cancer: Updated guidelines from the European Group on Tumor Markers (EGTM). Eur J Cancer 1990 2017; 75: 284-298

[27] Institute for Quality and Efficiency in Health Care. Biomarker-based tests to support the decision for or against adjuvant systemic chemotherapy in primary breast cancer. Extract. Cologne: Institut für Qualität und Wirtschaftlichkeit im Gesundheitswesen (IQWiG), 2016. Available at: https://www.iqwig.de/en/projects-results/projects/non-drug-interventions/d14-01-biomarker-based-tests-for-the-decision-for-or-against-adjuvant-systemic-chemotherapy-in-primary-breast-cancer.6097. html Accessed November 15, 2017

[28] Curigliano G, Burstein HJ, Winer PE et al. De-escalating and escalating treatments for early-stage breast cancer: the St. Gallen International Expert Consensus Conference on the Primary Therapy of Early Breast Cancer 2017. Ann Oncol 2017; 28: 1700-1712 